\title{
KAJIAN BIBLIOMETRIK TERHADAP ARTIKEL BIDANG TEKNOLOGI MINYAK DAN GAS BUMI DI INDONESIA (BIBLIOMETRIC STUDY OF THE OIL AND GAS TECHNOLOGY FIELD IN INDONESIA)
}

\author{
Himawanto ${ }^{1 *}$ \\ ${ }^{1}$ Pengelola Publikasi dan Dokumentasi Puslitbangtek Migas, LEMIGAS \\ *Korespondensi: himawanto@lemigas.esdm.go.id
}

\begin{abstract}
Energy problems is still a big topic and be a tough challenge in Indonesia so it is important to present a strategic move to seek a solution through research and study. Lembaran Publikasi Minyak dan Gas Bumi, Scientific Contribution Oil and Gas, dan Jurnal Teknologi Minyak dan Gas Bumi is the tool used by researchers to compile the results of innovative research and studies. To know the charge articles, authorship patterns, characteristics, and productivity of researchers used bibliometric study. During the period 2011-2013 as many as 91 researchers produced 159 articles. Most are the result of research on the exploitation of the technology by 71 articles (44.65\%), while the other main focus of exploration technologies such as achieving 17 articles (10.69\%). Coverage includes a research collaboration between countries, involving two to four researchers over the level of collaboration reached 61.01\%. Overall oil and gas research activities dominated R \& D institutions, universities and businesses.
\end{abstract}

\begin{abstract}
ABSTRAK
Permasalahan energi masih menjadi topik besar dan tantangan berat di Indonesia sehingga penting menghadirkan langkah strategis untuk mencari solusi, baik melalui penelitian maupun kajian. Lembaran Publikasi Minyak dan Gas Bumi, Scientific Contribution Oil and Gas, dan Jurnal Teknologi Minyak dan Gas Bumi merupakan sarana yang digunakan peneliti untuk menghimpun hasil penelitian dan kajian inovatifnya. Untuk mengetahui muatan artikel, pola kepengarangan, karakteristik, dan produktivitas peneliti digunakan kajian bibliometrik. Selama kurun waktu 2011 - 2013 sebanyak 91 peneliti menghasilkan 159 artikel. Hasil penelitian terbanyak berada pada teknologi eksploitasi sebesar 71 artikel (44,65\%), sedangkan fokus utama lain, seperti teknologi eksplorasi mencapai 17 artikel (10,69\%). Jangkauan kerja sama penelitian mencakup antarnegara, melibatkan dua hingga empat peneliti lebih dengan tingkat kolaborasi mencapai 61,01\%. Keseluruhan aktivitas penelitian minyak dan gas (migas) didominasi institusi penelitian dan pengembangan (litbang), perguruan tinggi, dan pelaku bisnis.
\end{abstract}

Keywords: Bibliometrics; Collaborative Authorship; Authorship; Content Analysis

\section{PENDAHULUAN}

Permasalahan energi yang bersumber dari energi fosil maupun energi alternatif masih menjadi topik besar di Indonesia. Penerapan teknologi juga menghadapi tantangan berat serta menjadi perhatian pemerintah dan para peneliti dari soal penemuan cadangan baru, peningkatan produksi, energi nonkonvensional, meroketnya harga minyak dunia, inefisiensi biaya, hingga tuntutan pencemaran lingkungan. Upaya untuk mereduksi emisi $\mathrm{CO}_{2}$ dalam rangka mitigasi perubahan iklim (Climate Change Mitigation), turut didemontrasikannya teknik $\mathrm{CO}_{2}$ Capture and Storage (CCS) yang memberikan solusi dalam menginjeksikan kembali CO2 ke dalam tanah dengan cara yang aman. Berbagai institusi telah melakukan penjajakan kerja sama dengan beberapa pusat riset dalam mengatasi permasalahan energi. Seiring dengan berkembangnya teknologi di sektor minyak dan gas bumi (migas) maka dianggap penting untuk menghadirkan langkah strategis dalam mencari solusi, baik melalui penelitian maupun kajian yang dapat diterapkan. Aktivitas penelitian dan kajian migas telah mendorong peneliti untuk 
memublikasikan hasil-hasil riset mereka kepada masyarakat sebagai jawaban atas persoalan yang tengah dihadapi. Sarana menghimpun penelitian dan kajian tersebut biasanya dilakukan melalui penerbitan jurnal yang berisikan informasi bermanfaat bagi industri, kalangan perminyakan, perguruan tinggi, dan umum. Pertumbuhan publikasi hasil-hasil riset sepatutnya diikuti juga dengan peningkatan sarana publikasi, khususnya jurnal yang akan memberi ruang bagi peneliti untuk menampung karya ilmiahnya dalam bentuk artikel. Namun, peningkatan demikian seharusnya berbanding simetris antara kuantitas dan kualitas artikel yang diterbitkan. Kualitas artikel dapat terukur melalui akreditasi dan bagi pusat riset, artikel yang diterbitkan oleh jurnal terakreditasi menjadi indikator utama dalam mengukur kontribusi peningkatan pengelolaan pengetahuan (KESDM, 2013). Akan tetapi, hingga saat ini jumlah jurnal terakreditasi yang menampung cakupan keilmuan migas masih memiliki kendala keterbatasan.

Jurnal Lembaran Publikasi Minyak dan Gas Bumi (LPMGB) dan Scientific Contribution Oil and Gas (SCOG) merupakan jurnal terakreditasi Puslitbangtek Migas LEMIGAS, sedangkan Jurnal Teknologi Minyak dan Gas Bumi (JTMGB) diterbitkan organisasi profesi Ikatan Ahli Teknik Perminyakan (IATMI). Ketiganya sebagai media publikasi nasional yang memuat hasil-hasil penelitian dan kajian di bidang migas. Pemilihan ketiga jurnal ilmiah tersebut dengan pertimbangan karena ketiganya merupakan media komunikasi ilmiah yang digunakan sebagai sarana komunikasi di antara para peneliti bidang migas untuk mempublikasikan dan menyebarluaskan hasil-hasil risetnya. Selain itu, pada penelitian ini juga diasumsikan bahwa sebagian besar hasil riset bidang migas di Indonesia dipublikasikan melalui ketiga jurnal ilmiah tersebut sehingga sangat menarik untuk diketahui karakteristiknya.

Adapun tujuan dari kajian ini untuk mengetahui muatan artikel, pola kepengarangan, karakteristik pengarang, dan produktivitas peneliti/pengarang bidang migas selama kurun waktu 2011 - 2013. Dari tujuan kajian yang hendak dicapai paling tidak akan memberi gambaran upaya kongkrit peneliti dalam memecahkan persoalan nasional yang tercermin dari ciri artikel ketiga jurnal. Dengan demikian, kajian ini dapat memberi manfaat bagi pemangku kepentingan di sektor migas dalam menilai dan merencanakan kegiatan riset sesuai fokus utama permasalahan.

\section{TINJAUAN PUSTAKA}

Bibliometrik berasal dari kata biblio atau bibliography yang berarti buku atau bibliografi, kemudian kata metrics yang memiliki kaitan dengan mengukur. Dengan demikian, istilah bibliometrik (bibliometrics) dapat diartikan menjadi mengukur atau menganalis buku atau literatur dengan pendekatan matematika dan statistika. Namun, hingga saat ini bibliometrik lebih banyak digunakan untuk mengukur terbitan berkala, seperti majalah ilmiah atau jurnal. Penerapan kajian bibliometrik pada jurnal terbagi dalam dua jenis, yaitu selain bersifat evaluatif, juga bersifat deskriptif. Kajian deskriptif biasanya menggambarkan ciri muatan sebuah jurnal, seperti jumlah halaman, frekuensi terbitan, dan jenis bahasa dengan tujuan karakteristiknya dapat dimengerti (Pattah, 2013: 48). Dengan demikian, manfaat bibliometrik dapat menjelaskan proses komunikasi tertulis dan sifat serta arah pengembangan sarana deskriptif, penghitungan, dan analisis berbagai faset komunikasi (Sulistyo-Basuki, 2002).

Faktor terpenting dalam proses komunikasi ilmiah tertulis sesungguhnya dimainkan oleh peran kepengarangan yang memegang tanggung jawab pertama terhadap publikasi karya ilmiah (Harande, 2001 dalam Natakusumah, 2014: 16). Dengan demikian, tanggung jawab tersebut akan dianggap sebagai kontribusi signifikan dan layak mendapatkan sebutan penulis (LIPI, 2012: 14). Tentunya penyebutan penulis bagi pengarang akan membawa efek positif bagi reputasi dan institusinya. Adapun gambaran 
institusi pengarang akan memberi ciri aspirasi wawasan yang dapat diketahui dari letak geografis tempat institusi tersebut berada. Selain itu, salah satu unsur yang tidak kalah penting dari kepengarangan, yaitu substansi artikel itu sendiri yang tercermin dari jenis bahasa yang digunakan. Kemudian, artikel yang beraspirasi wawasan internasional ditandai dengan banyaknya partisipasi penulis dari beberapa wilayah regional atau benua dengan penuangan karya ilmiahnya ke dalam bahasa internasional, seperti bahasa Inggris, dan umumnya media publikasi ilmiah yang menampung hasil-hasil riset tersebut telah masuk dalam daftar peringkat jurnal, seperti Scopus, SJR atau paling tidak Google Scholar.

Diungkapkan kembali peran kepengarangan tidak hanya sekadar penyebutan penulis saja, namun juga siapa saja yang telah memberi kontribusi hasil risetnya melalui jurnal-jurnal ilmiah. Wujud kontribusi peneliti pada jurnal ilmiah akan menjadi rekaman literatur yang dapat dimanfaatkan untuk mengetahui produktivitasya selama periode tertentu. Pada sisi lain, aspek kepengarangan juga terbentuk melalui susunan pengarang, baik secara individu maupun kolaborasi yang keduanya memiliki peranan pada sebuah karya ilmiah. Pengertian kolaborasi sendiri yaitu kerja sama antara lebih dari satu orang atau lebih dari satu lembaga dalam sebuah kegiatan, baik kegiatan penelitian maupun kegiatan pendidikan. Jenis kolaborasi peneliti terbagi atas kolaborasi dosen-mahasiswa, di antara teman sejawat, pengawasasisten, peneliti-konsultan, berbagai organisasi penelitian, dan kolaborasi internasional (Subramanyam, 1983 dalam Tambunan, 2013: 109).

Dikemukakan juga tingkat kolaborasi setiap disiplin ilmu berbeda satu sama lainnya. Data yang diperoleh dari jurnal terbitan dalam negeri terakreditasi LIPI di antaranya pada bidang kebumian menyebutkan tingkat kolaborasi Jurnal Riset Geologi dan Pertambangan 2011 mencapai 66.66\% (Prasetyahadi dan Nugroho 2014: 9). Berikutnya pada bidang rekayasa teknik dan teknologi, derajat kolaborasi Jurnal Teknologi Indonesia 2007 - 2011 sebesar 67,50\% (Natakusumah, 2014: 19). Kemudian pada jurnal bidang kimia yang terindek Scientific Journal Rangking (SJR), seperti Indonesian Journal of Chemistry (IJC) 2007 - 2011, tingkat kolaborasi yang dicapai sebesar 82,04\% (Maryono dan Sri Junandi, 2012: 20). Demikian juga jurnal terakreditasi dari perguruan tinggi, seperti Makara Seri Sains dan Jurnal Matematika dan Sains, tingkat kolaborasinya pada tahun 2010 mencapai 0,82\% dan 0,90\% (Anom, 2012: 39 - 40).

Berdasarkan hasil kajian bibliometrik jurnal di atas, dapat diambil sebuah pendapat bahwa kolaborasi memungkinkan para peneliti memperoleh kesempatan dan kemudahan mempublikasikan hasil-hasil riset dan kajian inovatifnya pada jurnal, utamanya pada jurnal bereputasi internasional. Kolaborasi akan memotivasi peneliti untuk berkarya bersama dan membawa dampak bagi peningkatan kualitas dan produktivitas riset.

\section{METODE}

Data yang digunakan pada kajian ini adalah semua hasil litbang migas di Indonesia periode 2011 - 2013 yang dipublikasikan pada jurnal LPMGB, SCOG, dan JTMGB. Ketiga jurnal pada kurun waktu tersebut terbit tiga kali dalam setahun dalam bentuk koleksi tercetak dan tersedia di Perpustakaan Lemigas. Guna melengkapi kebutuhan data, kajian ini juga memanfaatkan berbagai dokumen pendukung, seperti Peraturan Kepala LIPI No. 3 Tahun 2014 tentang Pedoman Akreditasi Terbitan Berkala Ilmiah, Peraturan Kepala LIPI No. 04/E/2012 tentang Pedoman Karya Tulis Ilmiah, dan Keputusan Kepala Badan Litbang ESDM No. 230.K/73/BLB/2011 tentang Pedoman Tata Kerja dan Hubungan antarKewenangan pada Badan Litbang ESDM. Dokumen peraturan tersebut berguna sebagai data 
pembanding dan untuk mengetahui level aspirasi wawasan artikel, kemudian penentuan standar minimal penggunaan sumber acuan, dan pengelompokan topik teknologi migas.

Metode pengumpulan data dilakukan melalui cara dokumentasi yang diperoleh melalui pemeriksaan dan pencatatan terhadap hasil riset migas di Indonesia selama periode 2011 - 2013 yang terpublikasi pada ketiga jurnal ilmiah tersebut. Terhadap data yang berhasil dikumpulkan kemudian dilakukan verifikasi khususnya nama pengarang dan afiliasinya guna menghindari ketidak-konsistenan dalam penulisan. Langkah selanjutnya yaitu mencatat komponen artikel ketiga jurnal dengan cara entri data ke dalam aplikasi Microsoft Excel 2010. Untuk merangkum dan mengolah muatan artikel jurnal meskipun bidang keilmuan berbeda-beda atau reputasi jurnalnya berbeda juga sebenarnya dapat memanfaatkan fasilitas yang ada pada aplikasi tersebut. Cerminan tersebut, tergambar pada Sethi dan Panda (2012: 88) dalam menghimpun artikel dan mengolah dua jurnal bidang Library and Information Science (LIS) atau pada kajian bibliometrik IJC 2007 - 2011 (Maryono dan Sri Junandi, 2012: 19). Selanjutnya, komponen entri menggunakan pendekatan daerah deskripsi bibliografi (ISBD), namun dibatasi sesuai kebutuhan pembahasan hasil kajian. Komponen tersebut, diantaranya judul, nama pengarang, volume, nomor terbitan, tahun jurnal, jumlah halaman, ilustrasi, tabel, dan sitiran.

Untuk menjawab tujuan kajian, dilakukan kegiatan analisis data menggunakan pendekatan bibliometrik. Kegiatan analisis dengan cara: (1) menghitung muatan artikel dengan pendekatan deskripsi bibliografi; (2) menganalisis pertumbuhan hasil riset migas setiap tahunnya menurut partisipasi institusi dan topik teknologi yang paling banyak diteliti; (3) melihat sebaran artikel sesuai jenis bahasa, kelamin pengarang, dan deskripsi fisik; (4) mengidentifikasi kepengarangan dan mengitung tingkat kolaborasinya, termasuk pola kerja sama antarwilayah dan tipe institusi; (5) mengamati karakteristik kemunculan pengarang utama/pembantu berdasarkan aspek geografis dan institusinya; dan (6) menganalisis produktivitas dan sebaran hasil riset menurut aspirasi wawasan.

Hasil analisis data kemudian disusun dalam bentuk tabulasi untuk keperluan pengamatan. Setelah itu data diolah, disusun berurutan, dan dihimpun untuk keperluan sajian pembahasan dalam bentuk tabel dan grafik serta interpretasi secara deskriptif.

\section{HASIL DAN PEMBAHASAN}

\subsection{Muatan Artikel}

Publikasi ketiga jurnal yang berhasil dihimpun menunjukkan kesamaan frekuensi penerbitan 3 kali dalam setahun sehingga seluruh publikasi selama tahun 2011 - 2013 mencapai 27 edisi dengan total 159 artikel yang dihasilkan dari kemunculan 318 peneliti/pengarang. Edisi jurnal memuat paling rendah 4 artikel, tertinggi 11 artikel, dan frekuensi kemunculan paling banyak 5 sampai 6 artikel. Volume artikel LPMGB lebih banyak di antara dua jurnal lainnya dan tahun 2012 - 2013 produktivitas ketiga jurnal mencapai angka seimbang 48 artikel (30,19\%). Produktivitas peneliti pada tahun 2012 - 2013 menurun jika dibandingkan tahun 2011 yang mencapai 63 artikel (39,62\%). Keadaan tersebut tidak hanya terjadi pada peneliti di bidang migas saja, di sektor pertanian, seperti yang terjadi pada peneliti Bbalitvet Deptan, produktivitasnya juga menurun setiap tahun sejak tahun 2008 - 2010 (Muhazan, 2011: 48). Kemudian pada bidang/teknik kimia, penulis artikel IJC mengalami tren penurunan sejak tahun 2009-2011 (Maryono dan Sri Junandi, 2012: 20). Dari kondisi tersebut, faktor yang dapat mempengaruhi tren publikasi ilmiah biasanya bisa dari dinamika perkembangan teknologi yang menyangkut bidang atau disiplin ilmu masing-masing sehingga 
menimbulkan pengaruh juga terhadap kontribusi peneliti/penulis dalam menyalurkan hasil risetnya (Anyi et al., 2009: 45).

Produktivitas ke-159 artikel memiliki muatan sumber acuan mencapai 1.915 sitiran, 1.400 ilustrasi, 558 tabel, serta bobot 1.544 halaman. Kandungan sitiran menandai bobot pemikiran dan gagasan yang dijadikan kerangka penulisan. Tentunya semakin banyak sumber acuan yang digunakan, utamanya acuan primer maka mutu artikel yang dimuat semakin baik. Kemudian, muatan lain yang menandai ciri khas jurnal kebumian, seperti jurnal bidang migas, yaitu ilustrasi dan tabel untuk mengarah pada efisiensi volume tulisan karena ada kalanya lebih lengkap dan informatif daripada bentuk narasi. Dari ulasan tersebut, volume ilustrasi dan tabel pada artikel bidang migas kemungkinan membawa dampak terhadap jumlah halaman yang dihasilkan. Selanjutnya, ciri halaman artikel jurnal pada umumnya berbeda dengan bentuk lain, seperti buku ilmiah yang berisi paling sedikit 49 halaman. Hasil kajian halaman ketiga jurnal menunjukkan rerata mencapai 9,71 halaman dan untuk menemukan kondisi yang identik dengan muatan ketiga jurnal tersebut, salah satunya ditemukan pada jurnal bidang kebumian lainnya, seperti Journal of Propulsion and Power (JPP) 1985 - 2013, rerata halamannya mencapai 7,84 halaman (Rao et al., 2014: 273). Dengan demikian, diperoleh hasil yang identik bahwa rerata halaman jurnal, baik yang terbit di dalam maupun luar negeri memiliki rerata kurang dari 10 halaman.

Selama periode 2011 - 2013, artikel yang dihasilkan merupakan wujud partisipasi satu hingga dua institusi lebih (Tabel 1) dan mayoritas dikontribusikan oleh satu institusi hingga mencapai 84,91\%. Wujud partisipasi satu institusi bukan berarti menandakan bahwa jumlah artikel terbanyak hanya dihasilkan oleh satu institusi saja, namun bisa juga dikontribusikan institusi lain dengan tipe institusi yang berbeda-beda. Kemudian, sisanya dua atau dua lebih institusi yang berpartisipasi maka dapat diasumsikan artikel yang dihasilkan telah tergolong karya riset kolaborasi.

Untuk mengetahui jenis riset migas yang dimuat pada ketiga jurnal, kajian ini mengelompokkan judul artikel menjadi sebuah topik teknologi dengan pendekatan tugas dan fungsi utama institusi litbang Puslitbangtek Migas LEMIGAS (Tabel 2). Fokus kegiatan riset pemerintah saat ini menitikberatkan pada sektor eksplorasi dan eksploitasi, dan dari hasil olah data memperlihatkan teknologi eksploitasi paling dominan dengan capaian 71 artikel (44,65\%). Salah satu solusi yang dicoba diangkat dalam teknologi ini berkaitan dengan persoalan peningkatan produksi migas dan energi nonkonvensional, seperti gas metana batubara, serta teknik $\mathrm{CO}_{2}$ Capture and Storage. Selanjutnya, di peringkat kedua, sumbangsih peneliti yang berkecimpung pada teknologi proses mencapai hasil 39 artikel (24,53\%). Bahasan mengenai topik tersebut mengulas tentang energi alternatif, seperti biodiesel yang dipercaya sebagai salah satu bahan bakar di masa depan sebagai pengganti energi fosil.

Berlanjut pada permasalahan krusial lain soal penemuan cadangan migas baru yang diangkat melalui topik teknologi eksplorasi, namun hasil riset yang dimuat hanya menempati peringkat keempat dengan hasil 17 artikel (10,69\%). Rendahnya topik tersebut dimungkinkan jumlah riset eksplorasi masih sedikit akibat kurangnya perhatian pemangku kepentingan atau pengaruh tingginya biaya investasi di sektor eksplorasi sehingga membawa dampak langsung terhadap hasil litbang yang dipublikasikan. Ketiga topik teknologi ini selain menjadi fokus utama juga menjadi perhatian serius pemerintah di tengah sumber migas yang semakin menipis. Topik ini juga memiliki keterkaitan dengan persoalan lain, seperti naiknya harga minyak dunia dan inefisiensi biaya produksi.

Sifat-sifat rekaman hasil riset (artikel) yang dimuat pada tiga jurnal diungkap dalam bentuk 
deskripsi bibliografi, seperti deskripsi judul yang memuat jenis bahasa, deskripsi pengarang sesuai jenis kelamin, dan deskripsi fisik. Pengungkapan demikian untuk mengetahui distribusi artikel dihasilkan sesuai sifat-sifat tersebut. Data pada Tabel 3 memperlihatkan judul artikel berbahasa Inggris sebesar 40,88\% lebih sedikit dibandingkan artikel yang ditulis dalam bahasa Indonesia. Penulisan dalam bahasa Inggris sebenarnya lebih membawa keuntungan bagi penulis dalam meningkatkan reputasi serta daya saing di kancah internasional. Namun, asumsi lain sepanjang topik yang diangkat menyangkut persoalan dalam negeri yang memiliki kaitan bila dihubungkan dengan target pembacanya, kemungkinan banyak pembaca menghendaki penulisan artikel ke dalam bahasa Indonesia. Hal demikian agar mempermudah proses komunikasi, menumbuhkan kegemaran membaca, dan memberdayakan jurnal-jurnal teknik skala nasional.

Capaian artikel yang dihasilkan penulis laki-laki sebanyak 75,47\% lebih tinggi dibandingkan penulis perempuan yang hanya $24,53 \%$. Melihat keadaan demikian dan untuk meningkatkan produktivitas perempuan dalam menghasilkan riset sehingga terwujud kesetaraan, semestinya setiap institusi tempat pengarang berasal menempuh langkah pembinaan melalui pola bimbingan peneliti senior ke peneliti junior, peningkatan jenjang pendidikan, atau mengupayakan peran kolaborasi penelitian.

Hasil maksimal pada bagian deskripsi bibliografi mengungkap kisaran 6 s.d. 10 halaman mencapai 101 artikel (63,52\%), kemudian 61 artikel (38,36\%) memiliki 6 s.d. 10 ilustrasi. Selain itu, frekuensi 1 s.d. 5 tabel sebanyak 128 artikel (80,50\%), dan pada bagian lain terdapat 73 artikel (45,91\%) dengan sumber acuan 10 s.d. 20 sitiran. Pada bagian analisis halaman artikel, tren kisaran di atas kemungkinan berpengaruh terhadap jumlah produkvitas artikel. Untuk menguatkan dugaan, kajian bibliometrik pada jurnal bidang litbang pertanian di India memperlihatkan kisaran 5 - 12 halaman menghasilkan artikel terbanyak hingga 67,94\% (Thanuskodi, 2012: 174). Selanjutnya, di bagian lain, ilustrasi dan tabel biasanya memiliki makna sebagai informasi ringkas hasil pembahasan sebuah artikel sehingga semakin banyak artikel memuat ilustrasi dan tabel maka banyak juga hasil yang dibahas. Kemudian, analisis sumber acuan 10 s.d. 20 sitiran, setidaknya kisaran terakhir (20 sitiran) dapat dijadikan standar minimal dalam penulisan karya ilmiah, khususnya acuan primer yang memiliki kemutakhiran guna meningkatnya kualitas tulisan peneliti/pengarang, namun tidak termasuk sitiran tulisan sendiri. Tentunya jumlah atau kisaran elemen fisik dari sebuah artikel dapat berbeda satu sama lain, tergantung pada disiplin ilmu dan pedoman penulisan karya tulis ilmiahnya.

Tabel 1. Partisipasi Institusi dalam Menulis Artikel Teknologi Migas

\begin{tabular}{|c|l|c|c|c|c|c|}
\hline \multirow{2}{*}{ No } & \multirow{2}{*}{ Partisipasi institusi } & \multicolumn{3}{|c|}{ Tahun } & Artikel & \multirow{2}{*}{ \% } \\
\cline { 3 - 5 } & & $\mathbf{2 0 1 1}$ & $\mathbf{2 0 1 2}$ & $\mathbf{2 0 1 3}$ & $\mathbf{n = 1 5 9 )}$ & \\
\hline 1 & Satu institusi & 55 & 42 & 38 & 135 & 84,91 \\
2 & Dua institusi & 8 & 6 & 8 & 22 & 13,84 \\
3 & > Dua institusi & 0 & 0 & 2 & 2 & 1,26 \\
\hline
\end{tabular}


Tabel 2. Distribusi Artikel Berdasarkan Topik Teknologi

\begin{tabular}{|c|l|c|c|c|c|c|}
\hline \multirow{2}{*}{ Peringkat } & \multirow{2}{*}{ Topik teknologi } & \multicolumn{3}{|c|}{ Tahun } & \multirow{2}{*}{$\begin{array}{c}\text { Artikel } \\
\text { (n=159) }\end{array}$} & \multirow{2}{*}{ \% } \\
\cline { 3 - 5 } & & $\mathbf{2 0 1 1}$ & $\mathbf{2 0 1 2}$ & $\mathbf{2 0 1 3}$ & \\
\hline 1 & Eksploitasi & 25 & 21 & 25 & 71 & 44,65 \\
2 & Proses & 16 & 9 & 14 & 39 & 24,53 \\
3 & Aplikasi Produk & 14 & 8 & 2 & 24 & 15,09 \\
4 & Eksplorasi & 5 & 7 & 5 & 17 & 10,69 \\
5 & Gas & 3 & 3 & 2 & 8 & 5,03 \\
\hline
\end{tabular}

Tabel 3. Distribusi Artikel Berdasarkan Deskripsi Bibliografi

\begin{tabular}{|c|c|c|}
\hline Deskripsi bibliografi & Artikel (n=159) & $\%$ \\
\hline \multicolumn{3}{|l|}{ Judul } \\
\hline Bahasa Indonesia & 94 & 59,12 \\
\hline Bahasa Inggris & 65 & 40,88 \\
\hline \multicolumn{3}{|l|}{ Pengarang } \\
\hline Laki-laki & 120 & 75,47 \\
\hline Perempuan & 39 & 24,53 \\
\hline \multicolumn{3}{|l|}{ Fisik } \\
\hline Halaman & & \\
\hline 1 s.d. 5 & 7 & 4,40 \\
\hline 6 s.d. 10 & 101 & 63,52 \\
\hline$>10$ & 51 & 32,08 \\
\hline \multicolumn{3}{|l|}{ Ilustrasi } \\
\hline 1 s.d. 5 & 54 & 33,96 \\
\hline 6 s.d. 10 & 61 & 38,36 \\
\hline$>10$ & 44 & 27,67 \\
\hline \multicolumn{3}{|l|}{ Tabel } \\
\hline 1 s.d. 5 & 128 & 80,50 \\
\hline 6 s.d. 10 & 27 & 16,98 \\
\hline$>10$ & 4 & 2,52 \\
\hline \multicolumn{3}{|l|}{ Sitiran } \\
\hline$<10$ & 68 & 42,77 \\
\hline 10 s.d. 20 & 73 & 45,91 \\
\hline 21 s.d. 30 & 13 & 8,18 \\
\hline 31 s.d. 40 & 3 & 1,89 \\
\hline 41 s.d. 50 & 1 & 0,63 \\
\hline 51 s.d. 60 & 0 & 0,00 \\
\hline 61 s.d. 70 & 1 & 0,63 \\
\hline
\end{tabular}




\subsection{Pola Kepengarangan}

Ciri hasil litbang migas yang dimuat ketiga jurnal kurun waktu 2011 - 2013 merupakan wujud partisipasi satu hingga lebih dari empat peneliti/pengarang (Tabel 4). Ciri kepengarangan setiap disiplin ilmu bisa berbeda satu sama lain, tergantung kerumitan persoalan yang akan dipecahkan. Namun, kondisi lain yang dapat digunakan sebagai gambaran penyeimbang di antaranya kepengarangan pada skala internasional dari salah satu kegiatan negara peserta G15, seperti riset nanoteknologi, ternyata pelaksanaan penelitiannya dilakukan oleh satu hingga tiga peneliti lebih dan hasil kolaborasinya memiliki rerata hingga (0,9) lebih (Karpagam et al., 2011: 72). Pola kepengarangan tersebut tidak jauh berbeda dengan riset migas yang dilakukan peneliti, seperti termuat pada publikasi ilmiah ketiga jurnal bidang migas.

Pola kepengarangan satu penulis menghasilkan artikel sebesar 38,99\%. Keadaan ini memperlihatkan pola kepengarangan individu menempati peringkat terendah dalam memecahkan persoalan teknologi migas dibandingkan secara berkelompok. Telah diungkap sebelumnya bahwa pola berkelompok dapat memberikan kemudahan dan kesempatan. Namun, pola individu kemungkinan juga bisa memperoleh kesamaan apabila peneliti memiliki perhatian serius dalam mengatasi masalah. Faktor tambahan lain yang dapat memungkinkan adalah jika peneliti memiliki cukup kemampuan dilihat dari aspek senioritas, pengalaman kerja, dan tingkat pendidikan sehingga peneliti tersebut menganggap belum memerlukan bantuan peneliti lain. Untuk memperkuat dugaan tersebut, kajian bibliometrik mengenai tingkat kolaborasi peneliti pada program insentif "Semi Top-Down” Kemenristek 2008 - 2010 memperlihatkaan keadaan karya peneliti individu hingga 79,57\% (Handoyo dan Putera, 2012: 109). Kemudian, kajian bibliometrik lainnya mengenai produktifitas publikasi peneliti Balitkabi 2008 - 2010 menemukan karya individu pada jurnal primer sebesar 33,3\%, dengan rerata terbaik dicapai peneliti berusia lebih dari 50 tahun, pendidikan S-3, dan menjabat sebagai peneliti utama (Sutardji, 2012: 26-27). Kejadian di dua tempat menyangkut karya individu peneliti bukan berarti kajian bibliometrik ini ingin mereduksi peran peneliti tunggal, namun sebaliknya menjadi pemicu bagi peneliti riset migas untuk lebih mendorong kerja sama dengan peneliti lain. Menjadi lebih baik pemecahan persoalan di bidang teknologi, khususnya bidang migas dilakukan berkelompok daripada secara sendiri. Tentunya ada banyak keuntungan yang didapat apabila peneliti melakukan secara berkelompok.

Bentuk lain yang diungkap pada Tabel 5 memperlihatkan pola kepengarangan masing-masing jurnal selama tahun 2011 - 2013 memiliki ciri bahwa frekuensi lebih dari satu penulis memiliki kemunculan terbanyak dibandingkan satu penulis. Pengungkapan bentuk demikian agar dapat membedakan rangkuman pola kepengarangan ketiga jurnal serta menunjukkan kemandirian jurnal itu sendiri. Dengan demikian, ciri-ciri penulis yang berkontribusi di masing-masing jurnal dapat terukur dengan obyektif. Sering kali pola kepengarangan tiap jurnal berbeda satu sama lain, namun jika dihitung tingkat kolaborasinya secara gabungan ternyata menunjukan rerata positif sehingga jurnal yang lebih banyak memuat karya perorangan tentunya akan menjadi terangkat.

Untuk mengetahui tingkat kolaborasi ketiga jurnal digunakan formulasi (Subramanyam, 1983: 37): $\mathrm{C}=\mathrm{Nm} /(\mathrm{Nm}+\mathrm{Ns})$, di mana notasi “C” diartikan sebagai tingkat kolaborasi, "Nm” adalah jumlah artikel yang dihasilkan lebih dari satu penulis, notasi "Ns” adalah jumlah artikel yang dikontribusikan satu penulis, dan nilai "C" dinyatakan dalam satuan persentase (\%). Hasil yang diperoleh setelah perhitungan menunjukkan rerata kolaborasi ketiga jurnal mencapai angka 61,01\% melebihi standar keseimbangan sebesar 50,00\%. Angka kolaborasi ketiga jurnal membuktikan 
hasil-hasil riset yang dipublikasikan guna memecahkan persoalan migas di Indonesia banyak dilakukan secara bersama-sama.

Fluktuasi kolaborasi riset migas yang tercermin pada ketiga jurnal mampu dipertahankan pada level minimal 58,33\%, kemudian meningkat hingga 64,58\% pada tahun 2013 (Gambar 1). Fluktuasi sejak tahun 2011 - 2013 mengalami tren pasang surut, namun tetap konsisten melebihi standar keseimbangan Subramanyam. Tingkat kolaborasi riset pada tahun 2013 setidaknya menjadi nilai acuan kurang guna meningkatkan peran kolaborasi pada tahun berikutnya. Kejadian ini juga menandai tingginya semangat peneliti serta kesadaran untuk bekerja sama dengan peneliti lain dalam mencari solusi dan inovasi teknologi migas bagi kepentingan nasional di masa depan.

Pada Gambar 2 ditampilkan jenis permasalahan kompleks yang menjadikan alasan peneliti untuk berkolaborasi. Hasil menunjukkan teknologi aplikasi produk memperoleh kolaborasi terbanyak hingga 79,19\%, disusul teknologi gas mencapai 75,00\%. Teknologi aplikasi produk migas di antaranya mengupas persoalan pengembangan produk bahan bakar, utamanya yang ramah lingkungan sebagai upaya mereduksi tingkat polusi yang telah banyak meresahkan masyarakat. Demikian juga permasalahan teknologi gas yang salah satu sasaran utamanya menyolusikan percepatan pemanfaatan gas untuk sektor transportasi. Tingkat kolaborasi yang tinggi pada kedua topik teknologi tersebut bukan berarti menandakan bahwa persoalan migas di Indonesia telah terselesaikan. Untuk itu selain bersinergi, peran kolaborasi dalam riset migas masih harus ditingkatkan di antaranya melibatkan berbagai institusi riset lainnya, perguruan tinggi, dan pelaku bisnis di dalam dan luar negeri.

Untuk mengetahui jangkauan peneliti berkolaborasi dengan peneliti lain, dilakukan pemetaan pola kolaborasi menurut aspek geografis dan tipe institusinya (Tabel 6). Hasil riset yang dipublikasikan sebanyak 2 artikel (2,06\%) ternyata melibatkan peneliti dari negara lain, seperti terlihat pada pola kerja sama Indonesia dengan Inggris. Hasil riset tersebut berkaitan dengan teknologi eksplorasi yang melibatkan Robert J. Morley seorang peneliti geologi dari University of London. Kolaborasi yang melibatkan negara lain selama tahun 2011 - 2013 masih dirasakan kurang. Untuk itu, perlu ditingkatkan pertukaran ide/gagasan dari disiplin ilmu berbeda ataupun hasil-hasil riset dari negara maju, seperti Inggris dan negara lainnya yang berhasil menerapkan teknologi litbang migas.

Selain pola kolaborasi lingkup negara, pola kolaborasi lain dari hasil pengembangan aspek kewilayahan negara juga diungkap pada kajian ini. Hasil menunjukkan kerja sama peneliti antardua provinsi yang berdomisili di Jawa Barat dan DKI Jakarta mencapai 6 artikel (6,19\%), begitupun sebaliknya pola DKI Jakarta dan Jawa Barat menghasilkan 5 artikel (5,15\%), bahkan konsorsium riset migas juga melibatkan peneliti dari tiga provinsi di Indonesia (Jawa Timur - DI Yogyakarta DKI Jakarta) dengan hasil 1 artikel (1,03\%). Meskipun geografisnya masih pada kawasan yang sama di Pulau Jawa, namun kondisinya dapat dikatakan telah mengundang simpati peneliti dari wilayah provinsi lain untuk bekerja sama.

Masih terkait pola kolaborasi, diketahui tiga tipe institusi, seperti litbang, perguruan tinggi, dan Kontraktor Kontrak Kerja Sama (KKKS) paling dominan menghasilkan riset kolaborasi. Capaian artikel kolaborasi litbang mendominasi dengan hasil 56 artikel (57,73\%), disusul perguruan tinggi sebanyak 12 artikel (12,37\%), dan KKKS mencapai 6 artikel (6,19\%). Institusi litbang dan perguruan tinggi merupakan pilar utama yang telah banyak menghasilkan inovasi dan teknologi, sedangkan KKKS dan industri sebagai pelaku bisnis menjadi pemangku kepentingan pokok atas hasil-hasil riset migas. Dengan demikian ketiga jenis institusi penghasil riset kolaborasi dapat dikatakan memiliki 
hubungan keterkaitan yang sangat erat dalam kerangka produsen dan konsumen. Selain kolaborasi menurut tipe institusi yang sudah tergambar pada ketiga jurnal migas tersebut, masih terdapat beberapa tipe institusi lain yang berpotensi untuk diajak bekerja sama dan bersinergi untuk turut serta memecahkan persoalan migas nasional, di antaranya pemerintah daerah dan pemerintah pusat yang memiliki kewenenangan regulasi.

Tabel 4. Pola Kepengarangan Berdasarkan Jumlah Penulis

\begin{tabular}{|c|c|c|c|c|c|c|c|c|c|c|c|}
\hline \multirow{2}{*}{ Tahun } & \multicolumn{7}{|c|}{ Jumlah Penulis } & \multirow{2}{*}{ Jumlah } \\
\cline { 2 - 11 } & \multicolumn{2}{|c|}{ Satu } & \multicolumn{2}{|c|}{ Dua } & \multicolumn{2}{|c|}{ Tiga } & \multicolumn{2}{|c|}{ Empat } & \multicolumn{2}{|c|}{ Empat } & \\
\hline 2011 & 25 & $(39,68)$ & 22 & $(34,92)$ & 13 & $(20,63)$ & 3 & $(4,76)$ & 0 & $(0,00)$ & 63 \\
2012 & 20 & $(41,67)$ & 16 & $(33,33)$ & 11 & $(22,92)$ & 0 & $(0,00)$ & 1 & $(2,08)$ & 48 \\
2013 & 17 & $(35,42)$ & 12 & $(25,00)$ & 11 & $(22,92)$ & 6 & $(12,50)$ & 2 & $(4,17)$ & 48 \\
\hline Jumlah & $\mathbf{6 2}$ & $\mathbf{( 3 8 , 9 9 )}$ & $\mathbf{5 0}$ & $\mathbf{( 3 1 , 4 5 )}$ & $\mathbf{3 5}$ & $\mathbf{( 2 2 , 0 1 )}$ & $\mathbf{9}$ & $\mathbf{( 5 , 6 6 )}$ & $\mathbf{3}$ & $\mathbf{( 1 , 8 9 )}$ & $\mathbf{1 5 9}$ \\
\hline
\end{tabular}

Tabel 5. Pola Kepengarangan pada Jurnal

\begin{tabular}{|l|c|c|c|c|}
\hline Nama jurnal & $\begin{array}{c}\text { Satu penulis } \\
\text { (Ns) }\end{array}$ & $\begin{array}{c}\text { > Satu penulis } \\
\text { (Nm) }\end{array}$ & Jumlah & $\begin{array}{c}\text { Tingkat kolaborasi } \\
\text { C=Nm/(Nm+Ns) }\end{array}$ \\
\hline Jurnal LPMGB & 30 & 33 & 63 & 52,38 \\
Jurnal SCOG & 22 & 28 & 50 & 56,00 \\
Jurnal TMGB & 10 & 36 & 46 & 78,26 \\
\hline Jumlah & $\mathbf{6 2}$ & $\mathbf{9 7}$ & $\mathbf{1 5 9}$ & $\mathbf{6 1 , 0 1}$ \\
\hline
\end{tabular}

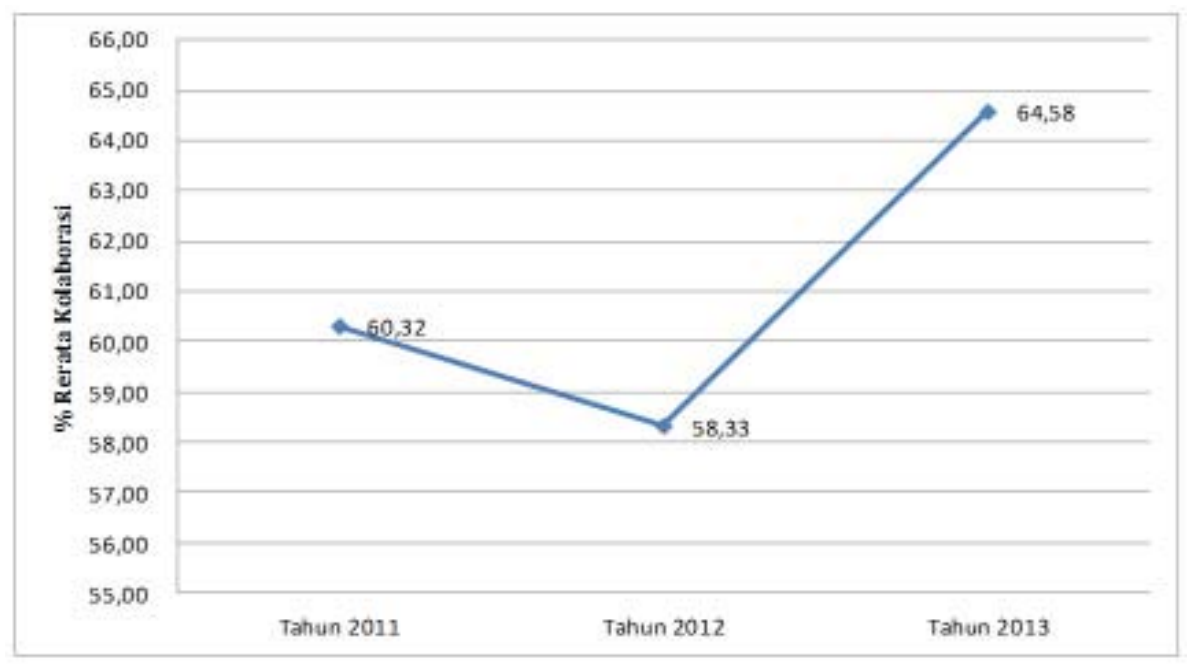

Gambar 1. Tingkat kolaborasi artikel teknologi migas 


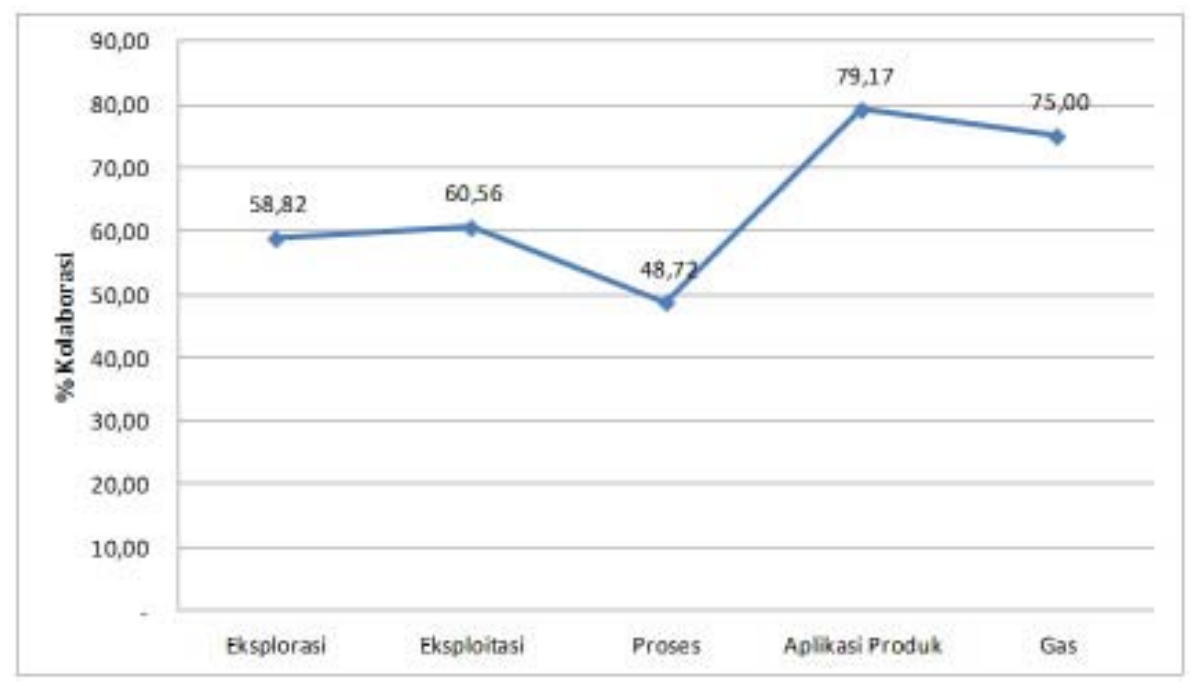

Gambar 2. Tingkat kolaborasi topik teknologi migas

Tabel 6. Pola Kerja Sama pada Artikel Teknologi Migas

\begin{tabular}{|c|c|c|c|c|}
\hline \multicolumn{3}{|c|}{ Bentuk kerja sama riset } & $\begin{array}{c}\text { Artikel kolaborasi } \\
\mathbf{n}=\mathbf{9 7}\end{array}$ & $\%$ \\
\hline \multicolumn{2}{|c|}{ Aspek Wilayah Negara } & & & \\
\hline $\begin{array}{l}1 \\
2\end{array}$ & $\begin{array}{l}\text { Negara } \\
\text { Negara }\end{array}$ & $\begin{array}{l}\text { Indonesia } \\
\text { Indonesia - Inggris }\end{array}$ & $\begin{array}{c}95 \\
2\end{array}$ & $\begin{array}{c}97,94 \\
2,06\end{array}$ \\
\hline \multicolumn{5}{|c|}{ Aspek Wilayah Provinsi } \\
\hline 1 & Provinsi & $\begin{array}{l}\text { DKI Jakarta } \\
\text { Jawa Barat } \\
\text { Riau } \\
\text { Sumatera Utara } \\
\text { DI Yogyakarta }\end{array}$ & $\begin{array}{c}63 \\
11 \\
1 \\
1 \\
1\end{array}$ & $\begin{array}{r}64,95 \\
11,34 \\
1,03 \\
1,03 \\
1,03\end{array}$ \\
\hline 2 & Provinsi & $\begin{array}{l}\text { Jawa Barat - DKI Jakarta } \\
\text { Jakarta - Jawa Barat } \\
\text { Jakarta - Surrey } \\
\text { Jawa Barat - Riau } \\
\text { Jawa Tengah - DKI Jakarta } \\
\text { Jawa Timur - DKI Jakarta } \\
\text { Sumatera Selatan - Jawa Barat } \\
\text { Banten - DKI Jakarta } \\
\text { Yogyakarta - DKI Jakarta }\end{array}$ & $\begin{array}{l}6 \\
5 \\
2 \\
1 \\
1 \\
1 \\
1 \\
1 \\
1\end{array}$ & $\begin{array}{l}6,19 \\
5,15 \\
2,06 \\
1,03 \\
1,03 \\
1,03 \\
1,03 \\
1,03 \\
1,03\end{array}$ \\
\hline 3 & Provinsi & Jawa Timur - DI Yogyakarta - DKI Jakarta & 1 & 1,03 \\
\hline \multicolumn{5}{|c|}{ Aspek Tipe Institusi } \\
\hline 1 & Tipe Institusi & $\begin{array}{l}\text { Litbang } \\
\text { Perguruan Tinggi } \\
\text { KKKS }\end{array}$ & $\begin{array}{l}56 \\
12 \\
6\end{array}$ & $\begin{array}{r}57,73 \\
12,37 \\
6,19\end{array}$ \\
\hline 2 & Tipe Institusi & $\begin{array}{l}\text { Litbang - Perguruan Tinggi } \\
\text { Perguruan Tinggi - Litbang } \\
\text { Perguruan Tinggi - KKKS } \\
\text { KKKS - Perguruan Tinggi } \\
\text { Industri - Litbang } \\
\text { Jasa Konsultan - Perguruan Tinggi } \\
\text { Kajian dan Terapan - Litbang } \\
\text { Litbang - KKKS } \\
\text { Litbang - Pengawas Hulu Migas }\end{array}$ & $\begin{array}{l}6 \\
6 \\
4 \\
2 \\
1 \\
1 \\
1 \\
1 \\
1\end{array}$ & $\begin{array}{l}6,19 \\
6,19 \\
4,12 \\
2,06 \\
1,03 \\
1,03 \\
1,03 \\
1,03 \\
1,03\end{array}$ \\
\hline
\end{tabular}




\subsection{Karakteristik Pengarang}

Analisis mengenai karakteristik pengarang dilakukan dengan mengelompokkan kemunculan 318 pengarang menurut peranannya sebagai pengarang utama atau pengarang pembantu. Pengungkapan karakteristik pada kajian ini lebih difokuskan pada peran pengarang pembantu untuk memberi gambaran seberapa besar kontribusinya dalam membentuk ciri berkolaborasi pada sebuah aktivitas riset migas. Kemudian, kemunculan pengarang pertama dapat diartikan sebagai pihak yang telah mewakili untuk kepentingan menghitung produktivitas penulis. Dari hasil pengolahan yang tersaji pada Tabel 7 terlihat rasio pengarang memiliki angka perbandingan yang sama sebesar (1,00\%). Komposisi seimbang pengarang utama dan pengarang pembantu dapat diartikan bahwa aktifitas ini telah membentuk karakter berkolaborasi karena setidaknya telah melibatkan dua pengarang. Dengan demikian, dapat diasumsikan kembali bahwa seluruh hasil riset migas yang dipublikasi ketiga jurnal adalah wujud karya kolaborasi.

Ada beberapa jenis karakteristik pengarang yang dapat diolah kembali, di antaranya dari aspek geografis yang datanya diperoleh dari keterangan afiliasi pengarang. Letak afiliasi tersebut kemudian dianalisis hingga level kewilayahan negara. Bagi pengarang yang berasal dari luar negeri dan untuk memudahkan pengelompokkan maka lokasi geografis pertama diasumsikan sebagai provinsi dan seterusnya. Hasil menunjukan wilayah tempat pengarang berasal, terdiri atas dua negara, sepuluh provinsi, dan lima belas kabupaten/kota.

Proporsi pengarang pembantu dari Indonesia sebesar (0,99\%) mendekati rasio $(1,00)$ sehingga dapat diartikan aktivitas riset migas yang dilaksanakan hampir seluruhnya membentuk karakter berkolaborasi. Hasil selanjutnya pada wilayah provinsi, memperlihatkan pengarang pembantu dari Riau memiliki rasio $(3,00)$ atau tiga kali lipat dari pengarang utamanya. Ciri berikutnya ditunjukkan oleh pengarang dari DI Yogyakarta yang menunjukkan kontribusi dua pengarang $(2,00)$ pembantu tiap kali aktivitas riset. Adapun pembentukan karakter berkolaborasi dengan melibatkan kurang dari dua pengarang pembantu $(1,27)$ terlihat pada Provinsi Jawa Barat. Berikutnya bahasan mengenai aspek wilayah kabupaten/kota menunjukkan Depok dan Pekanbaru memiliki rasio pengarang pembantu yang baik hingga menyentuh angka $(3,00)$. Capaian yang positif ini menandakan Depok dan Pekanbaru paling kurang beranggotakan empat pengarang dalam melakukan kegiatan riset migas. Proporsi pengarang pembantu lebih dari sama dengan dua orang dapat memberikan kesempatan serta keleluasaan bagi pengarang utama untuk membentuk susunan kepengarangan dari berbagai aspek, seperti disiplin ilmu berbeda, tingkat pendidikan, dan pengalaman kerja yang dapat mendukung keberhasilan aktivitas riset migas.

Karakteristik lain yang dikemukakan pada kajian ini mengulas mengenai afiliasi tempat pengarang berasal yang dikelompokkan menurut tipe dan nama institusinya (Tabel 8). Dari hasil analisis tipe insitusi dapat diketahui rasio pengarang pembantu kurang dari dua orang terdapat di perguruan tinggi (1,50\%) dan KKKS (1,42\%). Hasil demikian dapat dikatakan bahwa setiap aktivitas riset oleh kedua tipe insitusi melibatkan satu hingga dua orang pengarang pembantu. Kemudian analisis mengenai tipe institusi litbang diperoleh indeks $(0,87)$, dan menandakan bahwa hanya sebagian besar saja kegiatan riset telah dilakukan dengan berkolaborasi. Kedua tipe institusi, seperti litbang dan perguruan tinggi yang menjadi pilar pokok dalam melahirkan teknologi dan inovasi, sebaiknya masih harus meningkatkan proporsi pengarang pembantu pada setiap aktivitas riset, utamanya pada tipe insitusi pengguna, seperti pelaku bisnis migas ataupun industri.

Hasil analisis yang memperlihatkan kontribusi lebih dari sama dengan dua pengarang pembantu 
dicapai Universitas Indonesia dan PT. Chevron Pacific Indonesia dengan rasio sebesar $(3,00)$, disusul VICO Indonesia dengan hasil (2,00). Selanjutnya, keterlibatan satu hingga dua pengarang pembantu terdapat pada Universitas Trisakti $(1,50)$ dan Institut Teknologi Bandung $(1,13)$. Adapun proporsi hingga satu pengarang pembantu ditunjukan Puslitbangtek Migas LEMIGAS $(0,86)$, berikutnya PT. Energi Mega Persada dan Universitas Pembangunan Nasional "Veteran” masingmasing $(0,50)$. Karakteristik kepengarangan yang terbentuk sebaiknya bukan semata-mata pada tingkatan institusi saja atau pada level yang sama tempat peneliti berasal, namun juga melahirkan konsensus tentang urgensinya menumbuhkan kerja sama.

Tabel 7. Karakteristik Geografis Pengarang pada Artikel Teknologi Migas

\begin{tabular}{|l|c|c|c|c|c|}
\hline \multirow{2}{*}{ Karakteristik Geografis } & \multicolumn{3}{|c|}{ Frekuensi Kemunculan (n=318) } & \multirow{2}{*}{ Rasio } \\
\cline { 2 - 5 } & Utama(U) & $\mathbf{9}$ & Pembantu(P) & $\mathbf{9}$ & $\mathbf{( P / U )}$ \\
\hline Geografis Negara & & & & & \\
Indonesia & 159 & 50,00 & 157 & 49,37 & 0,99 \\
Inggris & 0 & 0,00 & 2 & 0,63 & - \\
\hline Geografis Provinsi & & & & & \\
DKI Jakarta & 128 & 40,25 & 119 & 37,42 & 0,93 \\
Jawa Barat & 22 & 6,92 & 28 & 8,81 & 1,27 \\
DI Yogyakarta & 2 & 0,63 & 4 & 1,26 & 2,00 \\
Riau & 1 & 0,31 & 3 & 0,94 & 3,00 \\
Banten & 1 & 0,31 & 1 & 0,31 & 1,00 \\
Jawa Tengah & 1 & 0,31 & 1 & 0,31 & 1,00 \\
Jawa Timur & 2 & 0,63 & 0 & 0,00 & 0,00 \\
Sumatera Utara & 1 & 0,31 & 1 & 0,31 & 1,00 \\
Sumatera Selatan & 1 & 0,31 & 0 & 0,00 & 0,00 \\
Surrey & 0 & 0,00 & 2 & 0,63 & - \\
\hline Geografis Kabupaten/Kota & & & & & \\
Jakarta Selatan & 125 & 39,31 & 116 & 36,48 & 0,93 \\
Bandung & 18 & 5,66 & 19 & 5,97 & 1,06 \\
Depok & 3 & 0,94 & 9 & 2,83 & 3,00 \\
Jakarta Barat & 3 & 0,94 & 3 & 0,94 & 1,00 \\
Pekanbaru & 1 & 0,31 & 3 & 0,94 & 3,00 \\
Sleman & 2 & 0,63 & 1 & 0,31 & 0,50 \\
Banyumas & 1 & 0,31 & 1 & 0,31 & 1,00 \\
Medan & 1 & 0,31 & 1 & 0,31 & 1,00 \\
Tangerang Selatan & 1 & 0,31 & 1 & 0,31 & 1,00 \\
Cirebon & 1 & 0,31 & 0 & 0,00 & 0,00 \\
Gresik & 1 & 0,31 & 0 & 0,00 & 0,00 \\
Jember & 1 & 0,31 & 0 & 0,00 & 0,00 \\
Prabumulih & 1 & 0,31 & 0 & 0,00 & 0,00 \\
Yogyakarta & 0 & 0,00 & 3 & 0,94 & - \\
Egham & 0 & 0,00 & 2 & 0,63 & - \\
\hline Total & $\mathbf{1 5 9}$ & $\mathbf{5 0 , 0 0}$ & $\mathbf{1 5 9}$ & $\mathbf{5 0 , 0 0}$ & $\mathbf{1 , 0 0}$ \\
\hline
\end{tabular}


Tabel 8. Karakteristik Institusi Pengarang pada Artikel Teknologi Migas

\begin{tabular}{|l|c|c|c|c|c|}
\hline \multirow{2}{*}{ Karakteristik Institusi } & \multicolumn{3}{|c|}{ Frekuensi Kemunculan (n=318) } & Rasio \\
\cline { 2 - 5 } & Utama(U) & $\mathbf{9}$ & Pembantu(P) & $\mathbf{9}$ & (P/U) \\
\hline Tipe Institusi & & & & & \\
Penelitian dan Pengembangan & 120 & 37,74 & 104 & 32,70 & 0,87 \\
Perguruan Tinggi & 24 & 7,55 & 36 & 11,32 & 1,50 \\
Kontraktor Kontrak Kerja Sama & 12 & 3,77 & 17 & 5,35 & 1,42 \\
Kajian dan Terapan & 1 & 0,31 & 1 & 0,31 & 1,00 \\
Industri & 1 & 0,31 & 0 & 0,00 & 0,00 \\
Jasa Konsultan & 1 & 0,31 & 0 & 0,00 & 0,00 \\
Pengawas Hulu Migas & 0 & 0,00 & 1 & 0,31 & - \\
\hline Nama Institusi & & & & & \\
Puslitbangtek Migas LEMIGAS & 117 & 36,79 & 101 & 31,76 & 0,86 \\
Institut Teknologi Bandung & 15 & 4,72 & 17 & 5,35 & 1,13 \\
Universitas Indonesia & 3 & 0,94 & 9 & 2,83 & 3,00 \\
VICO Indonesia & 3 & 0,94 & 6 & 1,89 & 2,00 \\
PT. Pertamina & 3 & 0,94 & 3 & 0,94 & 1,00 \\
Universitas Trisakti & 2 & 0,63 & 3 & 0,94 & 1,50 \\
OGRINDO-ITB & 2 & 0,63 & 2 & 0,63 & 1,00 \\
PT. Chevron Pacific Indonesia & 1 & 0,31 & 3 & 0,94 & 3,00 \\
PT. Energi Mega Persada & 2 & 0,63 & 1 & 0,31 & 0,50 \\
Universitas Pembangunan & 2 & 0,63 & 1 & 0,31 & 0,50 \\
Nasional “Veteran” & & & & & \\
Schlumberger & 2 & 0,63 & 0 & 0,00 & 0,00 \\
Balai Termodinamika Motor dan & 1 & 0,31 & 1 & 0,31 & 1,00 \\
Propulsi BPPT & & & & & \\
Pusat Penelitian Kelapa Sawit & 1 & 0,31 & 1 & 0,31 & 1,00 \\
Universitas Jenderal Soedirman & 1 & 0,31 & 1 & 0,31 & 1,00 \\
PT. LAPI - ITB & 1 & 0,31 & 0 & 0,00 & 0,00 \\
PT. Petrokimia Gresik & 1 & 0,31 & 0 & 0,00 & 0,00 \\
Star Energy (Kakap) Ltd & 1 & 0,31 & 0 & 0,00 & 0,00 \\
Universitas Jember & 1 & 0,31 & 0 & 0,00 & 0,00 \\
Universitas Gadjah Mada & 0 & 0,00 & 3 & 0,94 & - \\
University of London & 0 & 0,00 & 2 & 0,63 & - \\
BP Indonesia & 0 & 0,00 & 1 & 0,31 & - \\
BP Migas & 0 & 0,00 & 1 & 0,31 & - \\
ENI Indonesia & 0 & 0,00 & 1 & 0,31 & - \\
Kalrez Petroleum (Seram) & 0 & 0,00 & 1 & 0,31 & - \\
KSO Geo Minergy Sungai Lilin Ltd & 0 & 0,00 & 1 & 0,31 & - \\
\hline Total & $\mathbf{1 5 9}$ & $\mathbf{5 0 , 0 0}$ & $\mathbf{1 5 9}$ & $\mathbf{5 0 , 0 0}$ & $\mathbf{1 , 0 0}$ \\
\hline
\end{tabular}

\subsection{Produktivitas Penulis}

Dari hasil analisis kumpulan artikel kemudian dilakukan pengolahan untuk mengetahui produktivitas penulis pada ketiga jurnal kurun waktu 2011 - 2013. Data Tabel 9 memperlihatkan hasil 91 nama penulis memiliki produktifitas bervariasi antara satu hingga sepuluh artikel dengan rerata total penggunaan acuan mencapai 12,04 sitiran. Peringkat satu sampai tiga memperlihatkan produktivitas satu orang penulis mencapai enam sampai sepuluh artikel. Dari 91 nama yang produktif, penulis Puslitbangtek Migas LEMIGAS mencapai 51 orang. Kemudian, beberapa nama penulis pada ketiga jurnal dapat dikatakan telah memiliki reputasi pada kancah internasional karena masih dalam daftar pemeringkat, seperti Scopus. Namun, jumlah tersebut masih terbilang sedikit semisal nama Bambang Widarsono (Lemigas), Usman Pasarai (Lemigas), Edward M.L. Tobing (Lemigas), 
Eko Budi Lelono (Lemigas), dan Sudjati Rachmat (ITB). Pada nama lain yang bukan bagian kajian ini namun bermanfaat untuk memicu motivasi peneliti, setidaknya publik dapat menemukan lima belas nama penulis asal LIPI telah tercantum pada database Scopus (Tupan, 2013: 136). Dengan demikian sebaiknya capaian produktivitas penulis pada ketiga jurnal bidang migas harus diimbangi dengan kualitas standar penyebaran informasinya, utamanya yang berkarakter internasional, seperti Scopus.

Pada bagian lain jika dihitung reratanya maka produktivitas sepuluh artikel yang dicapai satu orang penulis dapat menandakan keaktifannya terbagi rata di ketiga jurnal selama kurun waktu 2011 - 2013. Dengan kata lain, setiap tahun penulis dapat menghasilkan paling kurang tiga artikel dan menyalurkannya ke masing-masing jurnal. Kondisi demikian tentunya akan membawa keuntungan bagi penulis dalam meningkatnya reputasi dan daya saing di antara komunitas peneliti migas, baik di tingkat nasional maupun internasional. Mengingat setiap jurnal biasanya memiliki target pembacanya sendiri, sebaiknya peneliti bidang migas lainnya dapat memperluas jangkauan publikasi hasil risetnya di berbagai jurnal, utama jurnal terakreditasi dan jurnal bereputasi internasional.

Rerata sitiran yang dihasilkan ketiga jurnal telah memenuhi standar minimal sebuah penulisan karya ilmiah yang dianjurkan LIPI, yaitu sekurang-kurangnya berjumlah sepuluh, utamanya acuan primer yang memiliki derajat kemutahiran dan biasanya bersumber dari terbitan berkala, seperti jurnal. Namun, hasil rerata ini masih perlu dikaji untuk mengetahui sejauh mana indikator-indikator yang dibatasi oleh LIPI telah terpenuhi oleh peneliti semisal pembatasan pada kutipan sendiri, dan tentunya kajian tersebut dapat menggunakan pendekatan bibliometrik. Kualitas sebuah tulisan pada jurnal dapat tergambar dari penggunaan acuan primernya, dengan demikian dapat memberikan gambaran juga terhadap kualitas hasil riset migas yang dihasilkan. Sisi positif lain yang dapat ditarik kembali dari rerata sitiran adalah tumbuhnya kesadaran para peneliti untuk lebih banyak membaca sumber literatur.

Selain penggunaan sitiran, hal lain yang dikemukakan terkait produktivitas penulis adalah rerata elemen fisik lainnya, seperti tabel dan gambar, sedangkan bahasan mengenai rerata halaman telah diungkap sebagian pada muatan artikel. Berdasarkan hasil yang didapat (Tabel 10) menunjukkan rerata tabel dan gambar mencapai angka 12,31. Bambang Widarsono sebagai produsen paling produktif memiliki rerata tabel dan gambar hingga 17.10 dan 11.80 halaman. Keadaan rerata tabel dan gambar mencerminkan banyaknya informasi ringkas hasil pembahasan yang dituangkan pada sebuah tulisan dan tentunya selain narasi penulisan, indikator tersebut dapat mempermudah komunikasi dengan pembaca dalam menangkap pesan inti sebuah pembahasan.

Guna mengetahui produktivitas penulis menurut aspek aspirasi wawasan, setiap artikel dilakukan pengelompokan berdasarkan wilayah tempat penulis berasal. Dari hasil olah data dapat diketahui ke-159 artikel ketiga jurnal terdistribusi pada dua wilayah geografis di Pulau Jawa dan Pulau Sumatera. Wilayah di Pulau Jawa terdiri atas enam provinsi dan Pulau Sumatera terdapat tiga provinsi (Tabel 11). Pulau Jawa paling produktif dan menempati urutan pertama dengan hasil 156 artikel (98,11\%) dan kontribusi penulis dari Pulau Sumatera sebesar 3 artikel (1,89\%). Melihat kondisi tersebut, dapat dikatakan bahwa ketiga jurnal memiliki ciri beraspirasi wawasan nasional ditandai dengan sekurangnya mencakup dua kawasan pulau di Indonesia dan kondisi tersebut paling tidak telah membentuk sebuah ciri jurnal terakreditasi.

Guna meningkatkan daya saing ketiga jurnal yang bukan sekadar beraspirasi wawasan nasional 
saja, sebaiknya pengelola publikasi mulai melakukan penjaringan ke berbagai institusi pemangku kepentingan di sektor migas untuk menyumbangkan tulisannya. Institusi lain yang berpotensi untuk dijaring pada level di atas nasional, seperti KKKS. Pertanyaannya adalah mengapa harus KKKS. Sebagaimana diketahui KKKS adalah instansi pemangku kepentingan strategis yang melakukan kegiatan bisnis migas di Indonesia namun lokasi geografisnya lebih banyak terdapat di luar negeri. Kemunculan pengarang utama KKKS dengan peringkat tiga besar pada ketiga jurnal (Tabel 9) merupakan wujud dari kegiatan bisnisnya selama ini. Dengan demikian, kepentingan bisnis tersebut harus diimbangi dan lebih ditingkatkan melalui penyaluran hasil-hasil risetnya di jurnal migas, seperti LPMGB, SCOG, dan JTMGB. Berbagai konferensi migas yang sudah banyak dilaksanakan di Indonesia justru memperlihatkan KKKS lebih sering menyumbangkan hasil risetnya ke dalam bentuk prosiding daripada ke jurnal bidang migas.

Masih mengenai produktivitas penulis, data pada Gambar 3 menampilkan sebaran penulis produktif di masing-masing provinsi. Untuk penentuan nilai produktivitas penulis yang terjadi di Jawa Timur dan Yogyakarta, terdapat dua nama berbeda dengan capaian artikel yang seimbang. Dalam hal ini, didasarkan pada jumlah sitiran terbanyak. Hasil ini dapat memberikan masukan bagi pemerintah setempat atau institusi penulis dalam memberi perhatian tersendiri, paling tidak untuk mempertahankan atau meningkatkan produktivitas penulis dalam melakukan riset-riset migas yang berkesinambungan. Pelaksanaan riset migas dengan tujuan untuk mengatasi persoalan nasional bukan semata-semata usaha satu pihak saja, namun harus mendapat dukungan dari pihak lain yang memiliki kepentingan sama.

Tabel 9. Produktivitas Penulis Menurut Aspirasi Wawasan

\begin{tabular}{|c|c|c|c|c|c|c|c|c|}
\hline Peringkat & $\begin{array}{c}\text { Artikel } \\
\text { (A) }\end{array}$ & $\begin{array}{c}\text { Penulis } \\
\mathbf{( P )}\end{array}$ & $\mathbf{\%}$ & $\begin{array}{c}\text { Total(T) } \\
=\mathbf{A x P}\end{array}$ & $\mathbf{\%}$ & $\begin{array}{c}\text { Sitiran } \\
\text { (S) }\end{array}$ & $\mathbf{\%}$ & $\begin{array}{c}\text { Rerata } \\
=\mathbf{S} / \mathbf{T}\end{array}$ \\
\hline 1 & 10 & 1 & 1,10 & 10 & 6,29 & 118 & 6,16 & 11,80 \\
2 & 7 & 1 & 1,10 & 7 & 4,40 & 51 & 2,66 & 7,29 \\
3 & 6 & 1 & 1,10 & 6 & 3,77 & 66 & 3,45 & 11,00 \\
4 & 5 & 4 & 4,40 & 20 & 12,58 & 337 & 17,60 & 16,85 \\
5 & 4 & 2 & 2,20 & 8 & 5,03 & 83 & 4,33 & 10,38 \\
6 & 3 & 9 & 9,89 & 27 & 16,98 & 335 & 17,49 & 12,41 \\
7 & 2 & 8 & 8,79 & 16 & 10,06 & 136 & 7,10 & 8,50 \\
8 & 1 & 65 & 71,43 & 65 & 40,88 & 789 & 41,20 & 12,14 \\
\hline \multicolumn{2}{|r|}{ Jumlah } & $\mathbf{9 1}$ & $\mathbf{1 0 0}$ & $\mathbf{1 5 9}$ & $\mathbf{1 0 0}$ & $\mathbf{1 . 9 1 5}$ & $\mathbf{1 0 0}$ & $\mathbf{1 2 , 0 4}$ \\
\hline
\end{tabular}


Tabel 10. Peringkat Pengarang dan Rerata Artikel Teknologi Migas

\begin{tabular}{|c|c|c|c|c|c|c|c|c|c|}
\hline \multirow{2}{*}{$\begin{array}{c}\text { No } \\
1\end{array}$} & \multirow{2}{*}{$\begin{array}{l}\text { Nama Pengarang } \\
\text { Bambang Widarsono }\end{array}$} & \multicolumn{2}{|c|}{$\begin{array}{l}\text { Artikel } \\
\text { (A) }\end{array}$} & \multicolumn{2}{|c|}{$\begin{array}{l}\text { Tabel+Gambar } \\
\text { (T) }\end{array}$} & \multicolumn{2}{|c|}{$\begin{array}{l}\text { Halaman } \\
\text { (H) }\end{array}$} & \multirow{2}{*}{$\begin{array}{c}\mathbf{T} / \mathbf{A} \\
17,10\end{array}$} & \multirow{2}{*}{$\begin{array}{l}\mathbf{H} / \mathbf{A} \\
11,80\end{array}$} \\
\hline & & 10 & $(6,29)$ & 171 & $(8,73)$ & 118 & $(7,64)$ & & \\
\hline 2 & Edward M.L. Tobing & 7 & $(4,40)$ & 115 & $(5,87)$ & 77 & $(4,99)$ & 16,43 & 11,00 \\
\hline 3 & Eko Budi Lelono & 6 & $(3,77)$ & 48 & $(2,45)$ & 72 & $(4,66)$ & 8,00 & 12,00 \\
\hline 4 & Oberlin Sidjabat & 5 & $(3,14)$ & 42 & $(2,15)$ & 49 & $(3,17)$ & 8,40 & 9,80 \\
\hline 5 & Utomo Pratama Iskandar & 5 & $(3,14)$ & 31 & $(1,58)$ & 44 & $(2,85)$ & 6,20 & 8,80 \\
\hline 6 & R. Desrina & 5 & $(3,14)$ & 20 & $(1,02)$ & 44 & $(2,85)$ & 4,00 & 8,80 \\
\hline 7 & Lisna Rosmayati & 5 & $(3,14)$ & 65 & $(3,32)$ & 50 & $(3,24)$ & 13,00 & 10,00 \\
\hline 8 & Djoko Sunarjanto & 4 & $(2,52)$ & 19 & $(0,97)$ & 35 & $(2,27)$ & 4,75 & 8,75 \\
\hline 9 & Maymuchar & 4 & $(2,52)$ & 40 & $(2,04)$ & 28 & $(1,81)$ & 10,00 & 7,00 \\
\hline 10 & Nofrizal & 3 & $(1,89)$ & 28 & $(1,43)$ & 28 & $(1,81)$ & 9,33 & 9,33 \\
\hline 11 & Sudjati Rachmat & 3 & $(1,89)$ & 46 & $(2,35)$ & 33 & $(2,14)$ & 15,33 & 11,00 \\
\hline 12 & Usman Pasarai & 3 & $(1,89)$ & 29 & $(1,48)$ & 37 & $(2,40)$ & 9,67 & 12,33 \\
\hline 13 & Milda Fibria & 3 & $(1,89)$ & 24 & $(1,23)$ & 19 & $(1,23)$ & 8,00 & 6,33 \\
\hline 14 & M. Hanifuddin & 3 & $(1,89)$ & 31 & $(1,58)$ & 23 & $(1,49)$ & 10,33 & 7,67 \\
\hline 15 & Sugihardjo & 3 & $(1,89)$ & 38 & $(1,94)$ & 30 & $(1,94)$ & 12,67 & 10,00 \\
\hline 16 & Zulkifliani & 3 & $(1,89)$ & 13 & $(0,66)$ & 18 & $(1,17)$ & 4,33 & 6,00 \\
\hline 17 & Maizar Rahman & 3 & $(1,89)$ & 25 & $(1,28)$ & 20 & $(1,30)$ & 8,33 & 6,67 \\
\hline 18 & Emi Yuliarita & 3 & $(1,89)$ & 30 & $(1,53)$ & 27 & $(1,75)$ & 10,00 & 9,00 \\
\hline 19 & Heru Atmoko & 2 & $(1,26)$ & 31 & $(1,58)$ & 21 & $(1,36)$ & 15,50 & 10,50 \\
\hline 20 & Septi Anggraeni & 2 & $(1,26)$ & 39 & $(1,99)$ & 24 & $(1,55)$ & 19,50 & 12,00 \\
\hline 21 & Roza Adriany & 2 & $(1,26)$ & 20 & $(1,02)$ & 16 & $(1,04)$ & 10,00 & 8,00 \\
\hline 22 & Suliantara & 2 & $(1,26)$ & 18 & $(0,92)$ & 19 & $(1,23)$ & 9,00 & 9,50 \\
\hline 23 & M.S. Wibisono & 2 & $(1,26)$ & 16 & $(0,82)$ & 22 & $(1,42)$ & 8,00 & 11,00 \\
\hline 24 & Cahyo Setyo Wibowo & 2 & $(1,26)$ & 23 & $(1,17)$ & 14 & $(0,91)$ & 11,50 & 7,00 \\
\hline 25 & Anda Lucia & 2 & $(1,26)$ & 9 & $(0,46)$ & 8 & $(0,52)$ & 4,50 & 4,00 \\
\hline 26 & Muhammad Fuad & 2 & $(1,26)$ & 24 & $(1,23)$ & 17 & $(1,10)$ & 12,00 & 8,50 \\
\hline 27 & $\begin{array}{l}65 \text { orang masing- } \\
\text { masing } 1 \text { artikel }\end{array}$ & 65 & $(40,88)$ & 963 & $(49,18)$ & 651 & $(42,16)$ & 14,82 & 10,02 \\
\hline & Jumlah & 159 & (100) & 1.958 & (100) & 1.544 & (100) & 12,31 & 9,71 \\
\hline
\end{tabular}


Tabel 11. Produktivitas Penulis Menurut Aspirasi Wawasan

\begin{tabular}{|l|c|c|c|c|c|}
\hline Aspirasi Wawasan & Artikel (A) & $\mathbf{\%}$ & Sitiran (S) & $\mathbf{\%}$ & Rerata = S/A \\
\hline Pulau Jawa & 156 & 98,11 & 1885 & 98,43 & 12,08 \\
DKI Jakarta & 128 & 80,50 & 1504 & 78,54 & 11,75 \\
Jawa Barat & 22 & 13,84 & 301 & 15,72 & 13,68 \\
Jawa Timur & 2 & 1,26 & 35 & 1,83 & 17,50 \\
DI Yogyakarta & 2 & 1,26 & 14 & 0,73 & 7,00 \\
Jawa Tengah & 1 & 0,63 & 22 & 1,15 & 22,00 \\
Banten & 1 & 0,63 & 9 & 0,47 & 9,00 \\
\hline Pulau Sumatera & 3 & 1,89 & 30 & 1,57 & 10,00 \\
Sumatera Utara & 1 & 0,63 & 21 & 1,10 & 21,00 \\
Sumatera Selatan & 1 & 0,63 & 7 & 0,37 & 7,00 \\
Riau & 1 & 0,63 & 2 & 0,10 & 2,00 \\
\hline Jumlah & $\mathbf{1 5 9}$ & $\mathbf{1 0 0}$ & $\mathbf{1 9 1 5}$ & $\mathbf{1 0 0}$ & $\mathbf{1 2 , 0 4}$ \\
\hline
\end{tabular}

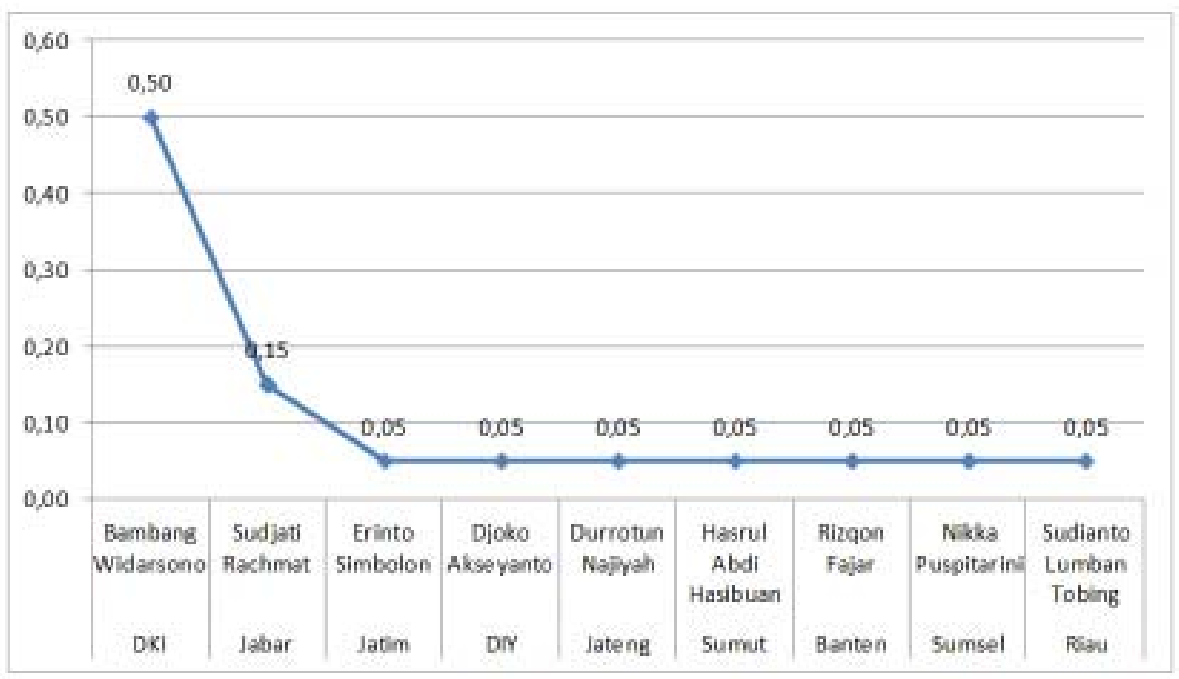

Gambar 3. Sebaran penulis produktif di 9 provinsi

\section{KESIMPULAN}

Berdasarkan hasil kajian bibliometrik terhadap artikel bidang teknologi migas di Indonesia dapat disimpulkan beberapa hal sebagai berikut.

1) Perkembangan riset migas nasional selama tahun 2011 - 2013 mencapai 159 kegiatan yang dikontribusikan oleh satu hingga dua jenis institusi lebih. Menurut kelompok topik, teknologi eksploitasi paling banyak diteliti hingga 44,65\%. Dari total kegiatan riset, peneliti laki-laki lebih banyak beraktivitas dan sebagian besar rekaman kegiatan riset ditulis ke dalam bahasa Indonesia dengan ciri-ciri lain 12,04 sitiran; 9,71 halaman; dan 12,31 tabel dan ilustrasi.

2) Sebagian besar kegiatan riset migas di Indonesia terus konsisten dikerjakan berkelompok dengan tingkat kolaborasi mencapai 61,01\% yang dilaksanakan oleh satu hingga lebih dari empat peneliti. 
Dari jumlah kolaborasi tersebut, teknologi aplikasi produk terbanyak membentuk kerja sama riset hingga 79,17\%. Kolaborasi riset dilaksanakan satu hingga dua tipe institusi dengan jangkauan antarnegara dan pada level nasional bisa melibatkan tiga provinsi.

3) Kemunculan peneliti dan pembantu peneliti dari seluruh kegiatan riset mencapai 318 kali serta memiliki komposisi seimbang (50:50). Kondisi ini menunjukkan kegiatan riset migas di Indonesia selama tahun 2011 - 2013 telah membentuk karakter berkolaborasi.

4) Sebanyak 91 peneliti menghasilkan satu hingga sepuluh karya ilmiah dengan produsen terbaik diperoleh Bambang Widarsono sebesar 6,29\% dan kemunculannya terbagi rata di ketiga jurnal. Kemudian, publikasi ilmiah bidang migas yang menampung hasil riset peneliti tergolong beraspirasi wawasan nasional dan sebagian nama penelitinya telah masuk dalam daftar peringkat internasional Scopus.

\section{SARAN}

Untuk meningkatkan reputasi jurnal Indonesia bidang migas pada skala internasional serta memacu minat peneliti dalam menyalurkan hasil riset migasnya diharapkan LPMGB, SCOG, dan JTMGB dapat masuk dalam daftar indeks Scopus (JIF), SJR atau GSM.

\section{UCAPAN TERIMAKASIH}

Terima kasih dan salam hormat disampaikan kepada Drs. Heribertus Joko Kristadi, M.Si. yang telah memberikan asistensi dalam penulisan karya ilmiah ini.

\section{DAFTAR PUSTAKA}

Anom S. 2012. "Kolaborasi Peneliti Bidang Sains: Sebuah Kajian Bibliometrik pada Makara Seri Sains dan Jurnal Matematika dan Sains Tahun 2010”. Skripsi. Depok: Universitas Indonesia.

Anyi, Kevin Wan Utap., A.N. Zainab, dan N.B. Anuar. 2009. "Bibliometric Studies on Single Journals: a Review”. Malaysian Journal of Library \& Information Science, 14 (1): 17 - 55.

Handoyo, Setiowiji dan Prakoso Bhairawa Putera. 2012. Tingkat Kolaborasi Peneliti pada Program Insentif "Semi Top-Down” Kementerian Riset dan Teknologi Tahun 2008-2010". Warta Kebijakan Iptek \& Manajemen Litbang, 10 (2): 99 - 114.

Harande, Yahaya Ibrahim. 2001. "Author Productivity and Collaboration: an Investigation of The Relationship Using The Literature of Technology. Libri, 51 (2): 124 - 127.

Karpagam, R., S. Gopalakrishnan, dan B. Ramesh Babu. 2011. "Publication Trend on Nanotechnology Among G15 Countries: A Bibliometric Study”. Collnet Journal of Scientometrics and Information Management, 5 (1): 61 - 80.

Keputusan Kepala Badan Litbang ESDM Nomor 230.K/73/BLB/2011. Pedoman Tata Kerja dan Hubungan antar Kewenangan pada Badan Litbang ESDM. Jakarta.

Maryono dan Sri Junandi. 2012. "Indonesian Journal of Chemistry 2007 - 2011: Analisis Kolaborasi dan Institusi. Visi Pustaka, 14 (3): 13 - 23.

Muhazan, Zakiah. 2011. “Analisis Sitiran Jurnal pada Artikel Peneliti Bbalitvet dalam Jurnal Ilmu Ternak dan Veteriner”. Jurnal Perpustakaan Pertanian, 20 (2) : 45 - 53.

Natakusumah, Engkos Koswara. 2014. "Penentuan Kolaborasi Penelitian dan Distribusi Pengarang pada Jurnal Teknologi Indonesia”. BACA: Jurnal Dokumentasi dan Informasi, 35 (1): 15 - 23.

Pattah, Sitti Husaebah. 2013. "Pemanfaatan Kajian Bibliometrika sebagai Metode Evaluasi dan Kajian dalam Ilmu Perpustakaan dan Informasi”. Khizanah Al-Hikmah, 1 (1): 47 - 57.

Peraturan Kepala Lembaga Ilmu Pengetahuan Indonesia Nomor 04/E/2012. Pedoman Karya Tulis Ilmiah. Jakarta.

Peraturan Kepala Lembaga Ilmu Pengetahuan Indonesia Nomor 3 Tahun 2014. Pedoman Akreditasi Majalah Ilmiah. Jakarta.

Peraturan Menteri Energi dan Sumber Daya Mineral Republik Indonesia Nomor 13 Tahun 2013. Penetapan Indikator Kinerja Utama di Lingkungan Kementerian Energi dan Sumber Daya Mineral. 
Jakarta.

Prasetyahadi, Abdurrakhman dan D.W. Ari Nugroho. 2014. “Kolaborasi Kepakaran Peneliti pada Jurnal Ilmiah LIPI Bidang Informatika dan Kebumian”. Visi Pustaka, 16 (1): 5 - 13.

Rao, K. Nageswara, Rajeev Kumar Sharma, S. Girija Devi, dan S. Muralidhar. 2014. "Bibliometric Analysis of the Journal of Propulsion and Power (1985-2013)”. Journal of Library \& Information Technology, 34 (3): $271-276$.

Sethi, Bipin Bihari dan K.C. Panda. 2012. "Growth and Nature of International LIS Research: an Analysis of Two Journal. International Information \& Library Review, 44 (2): 86 - 99.

Subramanyam, K. 1983. “Bibliometrics Studies of Research Collaboration: a Review”. Journal of Information Science, 6: $33-38$.

Sulistyo-Basuki. 2002. "Bibliometrika, Sainsmetrika, dan Informetrika. Kumpulan Makalah Kursus Bibliometrika. Depok: Universitas Indonesia.

Sutardji. 2012. "Produktivitas Publikasi Peneliti Balai Penelitian Tanaman Kacang-kacangan dan UmbiUmbian”. Jurnal Perpustakaan Pertanian, 20 (1): 1 - 9.

Tambunan, Kamariah. 2013. "Riset Unggulan Terpadu: Kajian Bibliometrika”. BACA: Jurnal Dokumentasi dan Informasi, 34 (2): 105 - 122.

Thanuskodi, S. 2012. “Bibliometric Analysis of Indian Journal of Agricultural Research”. International Journal of Information Dissemination and Technology, 2 (3): 170 - 175.

Tupan. 2013. “Kajian Sebaran Karya Ilmiah Peneliti LIPI yang Diindek oleh Data Base Scopus”. Visi Pustaka, 15 (3): $133-140$. 